\title{
Experimental study of a noise reducing barrier made of fly ash
}

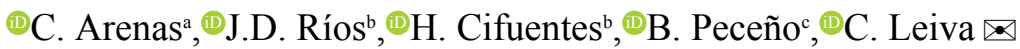 \\ a. Department of Chemical and Environmental Engineering, University of Seville, School of Engineering, (Seville, Spain). \\ b. Department of Continuum Mechanics and Structural Analysis, University of Seville, School of Engineering, (Seville, Spain) \\ c. Escuela de Prevención de Riesgos y Medioambiente, Facultad de Ciencias del Mar, Universidad Católica del Norte, (Coquimbo, Chile) \\ cleiva@us.es
}

\begin{abstract}
Although fly ash is commonly used as an additive to cement, large amounts of this material are disposed in landfills. To mitigate, it would be interesting to develop new products in which fly ash can be easily used and required in large quantities. In this work, fly ash is added to manufacture eco-friendly materials with acceptable acoustic and non-acoustic properties and a low cost. We built a barrier composed of fly ash (60 wt.\%), type II Portland cement (25 wt.\%), vermiculite (14.5 wt. $\%)$ and polypropylene fibers $(0.5 \mathrm{wt} . \%)$. The barrier complied with the mechanical requirements of European standards. The sound absorption coefficient and the airborne sound insulation were determined in a reverberation room, and the barrier was classified as A2 and B3. No leaching problems were observed.
\end{abstract}

KEYWORDS: Fly ash; Sound absorption; Airborne sound insulation; Heavy metals.

Citation/Citar como: Arenas, C.; Ríos, J.D.; Cifuentes, H.; Peceño, B.; Leiva, C. (2021) Experimental study of a noise reducing barrier made of fly ash. Mater. Construcc. 71 [341], e239 https://doi.org/10.3989/mc.2021.00220

RESUMEN: Estudio experimental de una barrera acústica compuesta de cenizas volantes . Aunque las cenizas volantes se usan comúnmente como una adición en la fabricación del cemento, grandes cantidades se siguen depositando en vertedero. Para mitigar este problema, es interesante desarrollar nuevos productos en los que las cenizas volantes se puedan usar fácilmente en grandes cantidades. En este trabajo, se emplean cenizas volantes para fabricar materiales con una alta absorción acústica, con propiedades mecánicas aceptables y un bajo coste. Se ha construido una barrera compuesta de cenizas volantes (60\% en peso), cemento Portland tipo II ( $25 \%$ en peso), vermiculita ( $14.5 \%$ en peso) y fibras de polipropileno $(0.5 \%$ en peso). La barrera cumplió con los requisitos mecánicos establecidos de las normas europeas. El coeficiente de absorción acústica y el aislamiento acústico en el aire se han determinado en una sala de reverberación, y la barrera se clasificó como A2 y B3. No se han observado problemas de lixiviación.

PALABRAS CLAVE: Cenizas volantes; Absorción acústica; Aislamiento acústico en el aire; Metales pesados.

Copyright: (C2021 CSIC. This is an open-access article distributed under the terms of the Creative Commons Attribution 4.0 International (CC BY 4.0) License. 


\section{INTRODUCTION}

Noise pollution can cause health problems to people, particularly when it is due to close proximity to overcrowded roads or highways. It is estimated that $40 \%$ of the population of the European Union (EU) is exposed to road traffic noise with an equivalent sound pressure level above $55 \mathrm{~dB}(\mathrm{~A})$ during the day and $30 \%$ of the population is exposed to it at night (1). A way of reducing traffic noise is the use of noise barriers (2). Conventional barriers are generally designed by using non-porous materials, so that a great proportion of the noise is reflected. Nonetheless, a problem is created when a minimization of sound levels is required on both sides of the road, since traffic noise barriers should absorb the noise and not reflect nor transmit it.

Waste is a problem from an environmental, social and economic point of view. Nowadays, a large amount of waste is generated and, consequently, great efforts are required to reduce, prevent and/or reuse it. The European Waste Directive $(3,4)$ promotes the recycling, reuse and extracting of valuable substances from waste, minimizing the disposal of waste in landfills and the consumption of natural raw materials. Thus, types of waste that used to be considered disposable in the past have potential value as a resource today.

In the last few years, construction materials composed of industrial waste (e.g., tyres, plastics, aluminium slags, marble dusts, foundry sands and recycled expanded polystyrene from recycling tetrabriks and other types of packaging) with interesting acoustical properties $(2,5)$ have been developed.

Although the recycling of industrial waste into raw materials has increased in recent years, low recycling rates are observed. In addition, few recycled construction materials have similar or better properties compared to commercial products. The key challenges are: (I) there is a lack of technical regulations on the use of waste in specific building materials; (II) many different chemical compounds, including dangerous ones (e.g., heavy metals) may be present in the waste depending on the production process involved; (III) prototypes and tests are required at semi-industrial scale to compare the properties of commercial and recycled materials; and (IV) some waste materials need previous treatments (e.g., sieving, gridding), which increases the final cost of the recycled material and hampers its financial viability.

Despite the reduction of coal consumption in favor of renewable energies, coal still provides $15 \%$ of global primary energy production in Spain and $37 \%$ in the United States. In 2018, only around 58\% of fly ash (FA) was reused in the USA (6), primarily as a concrete constituent, supplementary cementitious material, road construction soil amendment and structural fill (6) and, more recently, to develop geopolymers (7). New applications should be developed to promote and maximize the utilization of the unused fraction of FA.

The sound absorption coefficient of barriers mainly composed of fly ash was analyzed by using a Kundt tube at laboratory scale in a previous study (8). The results showed that a sound absorbing barrier composed of fly ash (60 wt.\%) had a similar sound absorption to that of typical acoustic barriers.

The main aim of this study was to develop a prototype of a sound absorbing barrier following a lowcost and simple manufacturing procedure similar to that of concrete noise barriers that can satisfy the requirements for road traffic noise reducing devices.

\section{MATERIALS AND METHODS}

\subsection{Materials}

Fly ash was obtained from traditional pulverized coal combustion. Portland cement, vermiculite and polypropylene fibers were also used.

We used type II Portland cement (PCII) with $32.5 \mathrm{MPa}$ compressive strength according to EN 197-1 (9). We used PCII because it was the most economically efficient cement. Although its mechanical properties were below $42.5 \mathrm{MPa}$, according to a previous study (8), mechanical properties of materials with $32.5 \mathrm{MPa}$ cement are appropriate.

Vermiculite is a hydrated silicate that contains iron, magnesium and aluminium and has very low specific density $\left(0.15 \mathrm{~g} / \mathrm{cm}^{3}\right)$. Materials used to manufacture sound absorbing devices usually contain vermiculite $(10,11)$. The vermiculite used in this study was a commercial product (VERLITE) manufactured in Asturias, Spain, with 85 wt.\% and particle size below $1.4 \mathrm{~mm}$. Polypropylene fibers range from 20 to $50 \mu \mathrm{m}$ in diameter and $40 \mathrm{~mm}$ in length. They were added to enhance flexural strength (12).

Table 1 shows the chemical composition, specific gravity and loss of ignition (LOI) of FA and PCII. The chemical composition was determined according to the ASTM D3682-13 standard test method (13). The main components in FA are $\mathrm{SiO}_{2}, \mathrm{Al}_{2} \mathrm{O}_{3}$ and $\mathrm{Fe}_{2} \mathrm{O}_{3}$. FA can be classified as an F-type ash in accordance to ASTM C 618-17 (14) that has a low content of $\mathrm{K}_{2} \mathrm{O} ; \mathrm{MgO}, \mathrm{Na}_{2} \mathrm{O}$ and $\mathrm{CaO}$.

Specific gravity was determined according to the EN 1097-7 standard (15). The specific gravity of the fly ash (2.7) was lower than that of PCII (3.1).

Figure 1 shows the particle size distribution of FA, where most of the particles had a size ranging between 0.2 and $100 \mu \mathrm{m}$, although the prevalent particle size ranged between 5 and $30 \mu \mathrm{m}$. Fly ash had a slightly lower particle size than PCII.

We performed a leaching test of the fly ash in accordance with EN 12457-4 (16) to determine any risk to the environment or human health due to the 
leaching of heavy metals. We compared the results obtained (Table 1) with the European Landfill Directive (17). The Directive establishes three different categories: inert, hazardous or non-hazardous. As shown on Table 1, FA can be classified as non-hazardous waste, with molybdenum content slightly above the inert waste limit. Note that this leaching test reproduces unfavorable conditions but does not adequately represent the behavior of the final construction material.

\subsection{Barrier composition}

Previous studies $(8,11)$ have determined the optimal fly ash/cement/vermiculite ratio to develop a material with high sound absorption - by using an impedance tube - and acceptable compressive strength using the highest possible amount of fly ash. In this study, we built a semi-industrial scale prototype based on the best dosage previously determined in (8) and tested it in an accredited laboratory. We also characterized other acoustic and non-acoustic parameters in much greater detail.

We concluded that $60 \mathrm{wt} . \%$ of fly ash is appropriate for developing an adequate sound absorbing porous material. We also used $14.5 \mathrm{wt} \%$ expanded vermiculite to increase open porosity. We added a dosage of $0.5 \mathrm{wt} \%$ polypropylene fibers to increase the mechanical properties based on a previous study (18). The composition of the barrier is presented in wt. $\%$ in Table 2 . However, the same values are very different when they are expressed in $\mathrm{v} / \mathrm{v} \%$ because of the specific densities of their components. Vermiculite $(\% \mathrm{v} / \mathrm{v})=76.1 ; \mathrm{FA}(\% \mathrm{v} / \mathrm{v})=17.2$; PCII $(\% \mathrm{v} / \mathrm{v})=6 \%$. The purpose of showing the values in wt. $\%$ rather than $\mathrm{v} / \mathrm{v} \%$ in Table 2 was to show the mixing dosage and allow researchers to reproduce these results.

\subsection{Barrier manufacture}

The solid components (i.e., fly ash, cement, vermiculite and fibers) were added in a vertical mixer and were rotated for 5 minutes. Next, water was poured into the mixer and rotated for another 15 minutes.

Due to the different particle size distribution of cement, fly ash and vermiculite, the mixture could be considered a mortar. This mortar was used to cast test specimens of different sizes and shapes for the different acoustic, mechanical and fire tests. They were demolded 24 hours later and cured for 27 days (relative humidity: $45 \%$, temperature: $20^{\circ} \mathrm{C}$ ). The intention was to manufacture the panels in a similar way as they are made in situ on the road. Higher relative humidity (e.g., submerging the samples in a water bath) could yield better mechanical properties

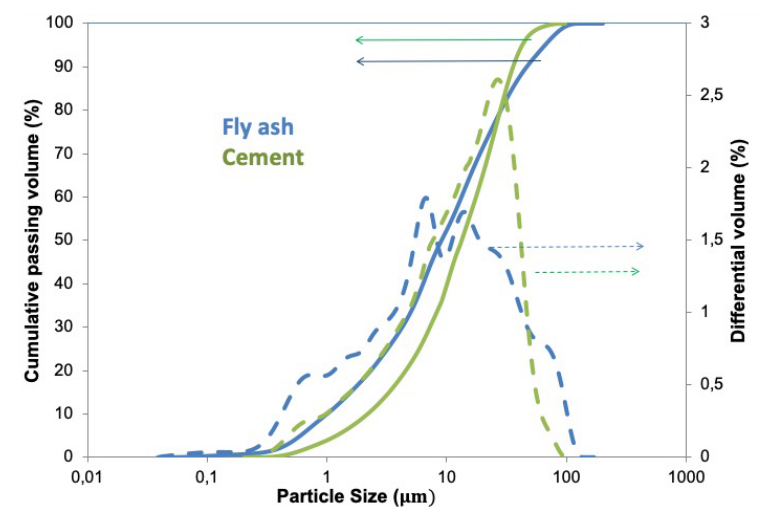

Figure 1. Particle size distribution of fly ash and cement.

TABLE 1. Chemical compositions of PCII and FA (wt.\%) and results of the leaching test (EN 12457-4). Comparison with the European Landfill Directive.

\begin{tabular}{cccccccc}
\hline & FA & PCII & $\begin{array}{c}\text { Leaching test } \\
(\mathbf{m g} / \mathbf{k g})\end{array}$ & FA & Inert & Non- hazardous & Hazardous \\
\hline $\mathbf{S i O}_{2}$ & 45.3 & 13.83 & $\mathbf{H g}$ & $<0.01$ & 0.01 & 0.2 & 2 \\
$\mathbf{A l}_{2} \mathbf{O}_{3}$ & 34.4 & 3.53 & $\mathbf{S e}$ & $<0.03$ & 0.10 & 0.5 & 7 \\
$\mathbf{M g O}$ & 1.9 & 0.7 & $\mathbf{B a}$ & 0.32 & 20.00 & 100 & 300 \\
$\mathbf{F e}_{2} \mathbf{O}_{3}$ & 2.4 & 2.26 & $\mathbf{P b}$ & $<0.03$ & 0.50 & 10 & 50 \\
$\mathbf{N a}_{2} \mathbf{O}$ & 0.4 & 0.08 & $\mathbf{C r}$ & 0.17 & 0.50 & 10 & 70 \\
$\mathbf{C a O}$ & 8.4 & 59.33 & $\mathbf{C d}$ & $<0.03$ & 0.04 & 1 & 5 \\
$\mathbf{T i O}_{2}$ & 1.4 & 0.19 & $\mathbf{M o}$ & 0.97 & 0.50 & 10 & 30 \\
$\mathbf{K}_{2} \mathbf{O}$ & 0.6 & 0.48 & $\mathbf{A s}$ & 0.21 & 0.50 & 2 & 25 \\
$\mathbf{S O}_{3}$ & 0.5 & 1.68 & $\mathbf{N i}$ & $<0.01$ & 0.40 & 10 & 40 \\
$\mathbf{L O I}$ & 3.5 & 15.5 & $\mathbf{C u}$ & $<0.01$ & 2.00 & 10 & 50 \\
Specific gravity & 2.72 & 3.10 & $\mathbf{Z n}$ & $<0.01$ & 4.00 & 20 & 50 \\
\hline
\end{tabular}


TABLE 2. Composition of the barrier.

\begin{tabular}{cccccc}
\hline & Fly ash (\% wt) & $\begin{array}{c}\text { Portland cement } \\
(\% \text { wt) }\end{array}$ & Vermiculite (\% wt) & Fibers (\% wt) & Water/solid ratio \\
\hline FA barrier & 60 & 25 & 14.5 & 0.5 & 0.5 \\
\hline
\end{tabular}

but did not influence the acoustic properties of the barrier.

\subsection{Test methods}

The barrier characterization (non-acoustic and acoustic) was conducted in compliance with the European standards for road traffic noise reducing devices. The legislation framework comprises EN 1793-1 (19) for acoustic characterization, and EN 1794-1 (20), EN 1794-2 (21) and EN 1794-3 (22) for non-acoustic properties. EN 14388 (23) shows the different requirements for these tests. The results were also compared to the properties of other construction materials commonly used in the same applications.

The sound absorption coefficient complied with EN ISO 354 (24) in the reverberation room. The test was performed in the INERCO-ACÚSTICA laboratory at $14{ }^{\circ} \mathrm{C}$, in a room with a volume of $150 \mathrm{~m}^{3}$, with a relative humidity of $32 \%$ and a static pressure of $1 \mathrm{~atm}$. The standard requires a minimum surface area of $10 \mathrm{~m}^{2}$. This requirement was adjusted to $3.08 \mathrm{~m}^{2}$ due to the limitations of the research methodology. Small samples and/or reverberation chambers are not new at all and there is great interest in them, despite the fact that they are not standardized $(25,26)$. Nevertheless, the room volume provides a diffuse sound field. Additionally, a previous study (25) showed a coefficient of determination of essays with limitations similar to those of our study versus standardized size, showing a coefficient of determination very close to 1 at frequencies higher than $400 \mathrm{~Hz}$. Consequently, it was determined that the results could be used for comparison purposes.

The acoustic absorption assessment index $\left(\mathrm{DL}_{\alpha}\right)$ was determined according to EN 1793-1 (19) from the sound absorption coefficient.

The transmission loss index $(R)$ was calculated using the airborne sound insulation test, as defined in EN 10140-2 (27) by the INASEL authorized laboratory. The data were the following: air temperature $17^{\circ} \mathrm{C}$, static pressure 1 atm, relative humidity $36 \%$, barrier surface $3.08 \mathrm{~m}^{2}$, receiver room volume $66.2 \mathrm{~m}^{3}$ and transmitter room volume $57.4 \mathrm{~m}^{3}$. The transmission loss assessment index $\left(\mathrm{DL}_{\mathrm{R}}\right)$ was determined according to EN 1793-2 (28).

The mechanical characteristics were determined experimentally. Compressive tests were carried out according to (29) using $50 \times 50 \times 50 \mathrm{~mm}$-sized cubes. All the cubes were made of the same matrix to avoid any differences in the properties of the material. The load was progressively increased at a rate of approximately $0.5 \mathrm{MPa} / \mathrm{s}$ until the specimen was completely ruptured. Flexural tests were carried out according to (30) using $40 \times 40 \times 160 \mathrm{~mm}$ samples. Impact strength tests were carried out according to (31) and superficial hardness tests were carried out according to (32), both on panels of $160 \times 160 \times 40 \mathrm{~mm}$.

The open void ratio (VR) was determined since it is strongly related to the acoustic behavior of materials. A vacuum water saturation method was followed (33). Samples were previously dried at $105^{\circ} \mathrm{C}$ in a furnace. Next, they were weighed (S1) and submerged in water in a vacuum vessel until saturation. Subsequently, they were lifted out of the water and weighed (S2). The open void ratio was determined as VR $(\%)=\mathrm{WV} / \mathrm{SV} \cdot 100$, where $\mathrm{WV}$ is the water volume and $\mathrm{SV}$ is the total volume of the sample. Water volume can be calculated as $\mathrm{WV}=(\mathrm{S} 2-\mathrm{S} 1) / \rho_{\mathrm{w}}$, wherein $\rho_{\mathrm{w}}$ is the water density. The density was determined by weight (S1) and volume (dimensions) of the samples. The $\mathrm{pH}$ was measured as defined in EN 12859 (32). Five grams of barrier were extracted and left in contact with water in a mass ratio of 10/1 (water/solid). The $\mathrm{pH}$ was measured after 5 minutes. The moisture content (MC) was determined according to EN 12859 (32). The mass of the barrier at ambient temperature $(\mathrm{C} 1)$ and after heating at $40{ }^{\circ} \mathrm{C}$ until reaching a constant mass $(\mathrm{C} 2)$ were determined. The $\mathrm{MC}$ value is $\mathrm{MC}=100 \cdot(\mathrm{C} 2-\mathrm{C} 1) / \mathrm{C} 1$.

Four different samples were tested for physical and mechanical characterization.

According to the environmental and general safety regulations defined in EN 1794-2 (22), the resistance of a noise reducing device must be measured in the case of a fire in the brushwood nearby. Hence, a fire test was carried out according to EN 1363-1 (34). For the fire test, small panels $(270 \times 320 \mathrm{~mm}$ and 20 and $40 \mathrm{~mm}$ thick) were prepared. These two thicknesses were chosen $(40 \mathrm{~mm}$ was the maximum) because the size of the furnace for the fire test did not make it possible to test panels of $120 \mathrm{~mm}$ in thickness.

As regards environmental safety, Table 2 shows that fly ash can be classified as non-hazardous waste and therefore that its use in acoustic barriers is not harmful to people or the environment Nevertheless, the final material was subjected to the NEN 7345 tank leaching test (35). This is a monolithic leaching test that makes it possible to assess the leaching of heavy metals from the final material and not only from the raw materials separately. This is 


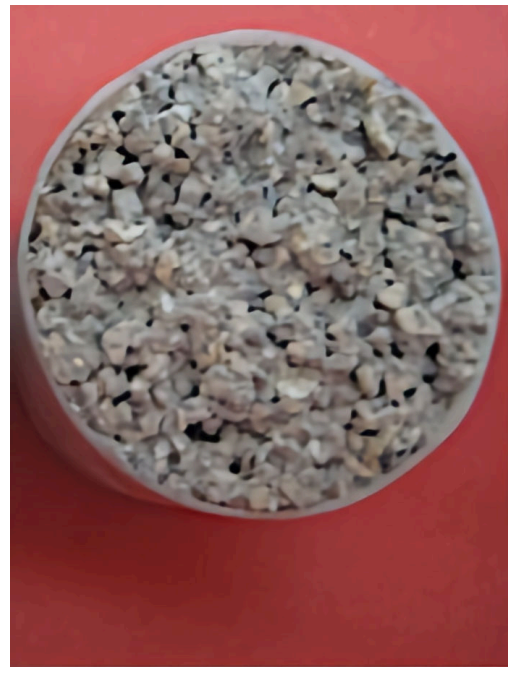

Figure 2. Sample of the FA barrier.

important when wastes are mixed with other solid materials like cement, because a solidification/stabilization process occurs. The main leaching factor in construction materials is rain, which mainly affects the outer surface of the construction material. One of the advantages of this test is that it simulates rain conditions.

\section{RESULTS}

All the acoustic and non-acoustic parameters required by the various standards for road traffic noise reducing devices using this material were assessed. Specifically, physical and mechanical properties, fire resistance and environmental impact; only wind resistance was not evaluated. It should be noted that some of the tests had limitations, which are mentioned in the text.

\subsection{Physical properties}

Physical properties are shown in Table 3. As observed, open porosity was high, although porous concretes, used as sound absorbing materials (composed only of cement and coarse aggregates) can reach $40 \%$ (36).

As observed in Figure 2, the porosity of the FA barrier presented a flaky structure due to the effect of the vermiculite and its pore size between 1 and $3 \mathrm{~mm}$, while porous concretes show values between 3 and $10 \mathrm{~mm}$ of pore size according to a previous study that used X-ray computed tomography (37). Open porosity is strongly dependent on particle size and increases when a larger aggregate is used. Typical porous concrete (with coarse aggregates between $5-10 \mathrm{~mm}$ ) has predominant pore sizes above $7 \mathrm{~mm}$ with a total porosity of $46 \%$, while FA barriers (with vermiculite particle size lower than $1.14 \mathrm{~mm}$ ) have pore sizes ranging mainly between 2 and $4 \mathrm{~mm}$ and a total porosity of $40 \%$.
According to EN 12859, the barrier was classified as medium density (between 800 and $1100 \mathrm{~kg}$ / $\mathrm{m}^{3}$ ). The density of the FA barrier was lower than that of a porous concrete commonly used to build road traffic noise reducing devices $\left(900-1100 \mathrm{~kg} / \mathrm{m}^{3}\right)$ (36). Despite this, the specific density of the fly ash and vermiculite was lower than that of cement and coarse aggregates $\left(2.7 \mathrm{~g} / \mathrm{cm}^{3}\right)$, resulting in a material with lower density. According to EN 12859, the barrier was classified as having normal $\mathrm{pH}$ (in the range between 6.5 and 10.5), which was lower than that of other barriers composed mainly of wastes (36). Moisture (M) was higher than in gypsum barriers (18) or other porous concretes (36). This was due to the fact that the water was located in the flaky structure of the FA barrier, while the larger pores of porous concrete cannot store much water.

\subsection{Mechanical properties}

Table 3 presents the mechanical properties of the barrier. Compressive and flexural strengths were low because of the porous and flaky nature of the barrier, which reduced the cohesion between the fly ash, cement and vermiculite. Other porous concretes with wastes have a compressive strength between 5 and $10 \mathrm{MPa}$ (37). Flexural strength was higher than 0.6 $\mathrm{MPa}$, the minimum level established for gypsum barriers (32), and higher than that of other porous concretes containing wastes $(5,36)$. The addition of fibers increased flexural strength due to its bridge effect, but this did not have a significant influence on compressive strength (18).

TABLE 3. Physical and mechanical properties of the barrier.

\begin{tabular}{llll}
\hline OVR (\% wt) & 32.0 & Compressive strength & $2.5 \mathrm{MPa}$ \\
Density (kg/m $)$ & 886.9 & Flexural strength & $1.3 \mathrm{MPa}$ \\
$\mathbf{p H}$ & 9.7 & Impact resistance & $18 \mathrm{~mm}$ \\
M (\% wt) & 7.2 & Superficial hardness & 42 Shore C \\
\hline
\end{tabular}

EN 1794-2 (21) sets the requirement of the strength of noise reducing devices to withstand the impact if stones thrown from the road. It establishes that barriers must resist the impact of stones. The impact resistance of the FA barrier was higher than that of other recycled porous barriers, in which the diameter of the ball mark was around $20 \mathrm{~mm}$ (36).

Superficial hardness was low compared to the values of other barriers made with similar dosages of wastes ( $>60$ Shore C) and was below the limits established for other types of barriers (non-acoustic applications: $>55$ Shore $\mathrm{C}$ for densities between 800 and $1000 \mathrm{~kg} / \mathrm{m}^{3}$ ) (37). The low superficial hardness was due to the effect of the expanded vermiculite, which is a highly elastic material and therefore reduces superficial hardness (38). 


\subsection{Acoustic properties}

Figure 3 shows the sound absorption coefficient from the reverberation room test. The absorption coefficient was low for frequency bands below $200 \mathrm{~Hz}$ and reached 0.7 at $4000 \mathrm{~Hz}$. This trend is comparable to the results shown by other researchers in noise reducing devices made from other wastes and with similar physical properties $(24,37)$.

The regulation establishes that $\mathrm{DL}_{\alpha}$ must be calculated according to (19), according to which the barrier was classified in Category A (see Table 4). $\mathrm{DL}_{\alpha}$ was $4.1 \mathrm{~dB}$, leading to the classification of the material as A2. Porous concretes have a slightly higher $\mathrm{DL}_{a}$, but they are classified in the same category $(39,40)$. Sound absorption is generally linked to the energy losses produced by the friction of sound waves in the wall holes. Thus, materials with a low open void ratio usually have a low sound absorption coefficient at different frequencies. However, the flaky structure of the FA barrier enables it to retain small air particles that absorb noise and reduce the reverberation time in a wide range of frequencies, increasing total absorption despite its low open porosity (41).

In addition, $\mathrm{R}$ was determined by adapting EN 1793-2 (28). Figure 3 presents the transmission loss of the FA barrier at different frequencies. From the transmission loss index, $\mathrm{DL}_{\mathrm{R}}$ can be obtained in accordance with the standard established in (28); this led to the classification of the product in Category B (see Table 4). The $\mathrm{DL}_{\mathrm{R}}$ of the fly ash-based product was $29 \mathrm{~dB}$, so the product was classified in Category B3. Commercial concrete barriers usually consist of a combination of two layers: one made of porous concrete (50-100 $\mathrm{mm}$ of thickness), which absorbs the noise, and a hard-backing layer of non-porous concrete (50-150 mm of thickness), which increases the transmission loss index. In this case, the FA barrier is composed of a single layer, which makes its manufacture easier. Nonetheless, the FA barrier belongs to the same category as porous concrete noise barriers $(40,41)$.

\subsection{Fire resistance}

Figure 4 shows the change of temperature versus time on the non-exposed surface of the barrier when

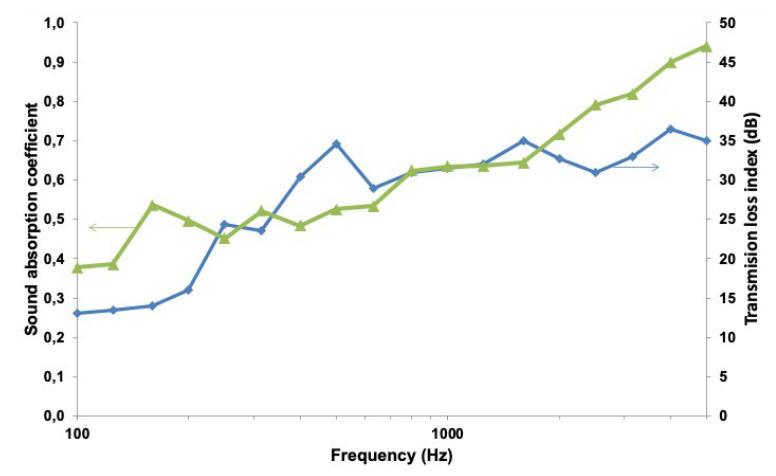

FIGURE 3. Sound absorption coefficient and transmission loss index at different frequencies.

the reverse is bearing the fire. Fire resistance can be defined as the time necessary to reach $180^{\circ} \mathrm{C}$ on the surface that is not exposed to the fire. This value was 22.4 and $34.2 \mathrm{~min}$ for barriers 20 and $40 \mathrm{~mm}$ thick, respectively. The duration of the evaporation plateau is the main factor that determines fire resistance. It is the time during which the temperature of the surface not exposed to fire remains constant at a temperature slightly below $100{ }^{\circ} \mathrm{C}$. This is because porous construction materials have a high water retention capacity $(7,42)$. Fire resistance was lower than in other barriers using gypsum as binder, due to the high chemically bound water included in the gypsum (43), but such barriers cannot be used in outdoor environments because they have durability problems. However, it was higher than in other typical porous concretes used in sound absorbing barriers (34), because the flaky structure contains more water than the coarse aggregates of traditional porous concretes. An increase of the thickness led to a higher fire resistance. Hence, a barrier $120 \mathrm{~mm}$ thick would have about $110 \mathrm{~min}$ of fire resistance (44). In addition, no smoke was emitted from the barrier at any time during the fire test.

After the fire test, we analyzed some physical and mechanical properties of the FA barrier (Table 5). The mechanical properties after the fire test decreased as a result of mass loss during the fire. This loss is related to the free (humidity) and chemically bound water of the mix, which increases porosity and reduces mechanical strength. The decrease of superficial hardness was lower on the non-exposed surface, because the temperatures were lower than those on the exposed surface.

TABLE 4. Different categories according to $\mathrm{DL}_{\alpha}(19)$ and $\mathrm{DL}_{\mathrm{R}}(28)$.

\begin{tabular}{lcccccc}
\hline Categories for sound absorption & $\mathbf{A 0}$ & $\mathbf{A 1}$ & $\mathbf{A 2}$ & $\mathbf{A 3}$ & $\mathbf{A 4}$ & $\mathbf{A 5}$ \\
\hline $\mathbf{D L}_{\alpha}$ & Not determined & $<4$ & $4-7$ & $8-11$ & $12-15$ & $>15$ \\
Categories for sound insulation & $\mathrm{B} 0$ & $\mathrm{~B} 1$ & $\mathrm{~B} 2$ & $\mathrm{~B} 3$ & $\mathrm{~B} 4$ & \\
$\mathbf{D L}_{\mathrm{R}}$ & Not determined & $<15$ & $15-24$ & $25-34$ & $>34$ & \\
\hline
\end{tabular}




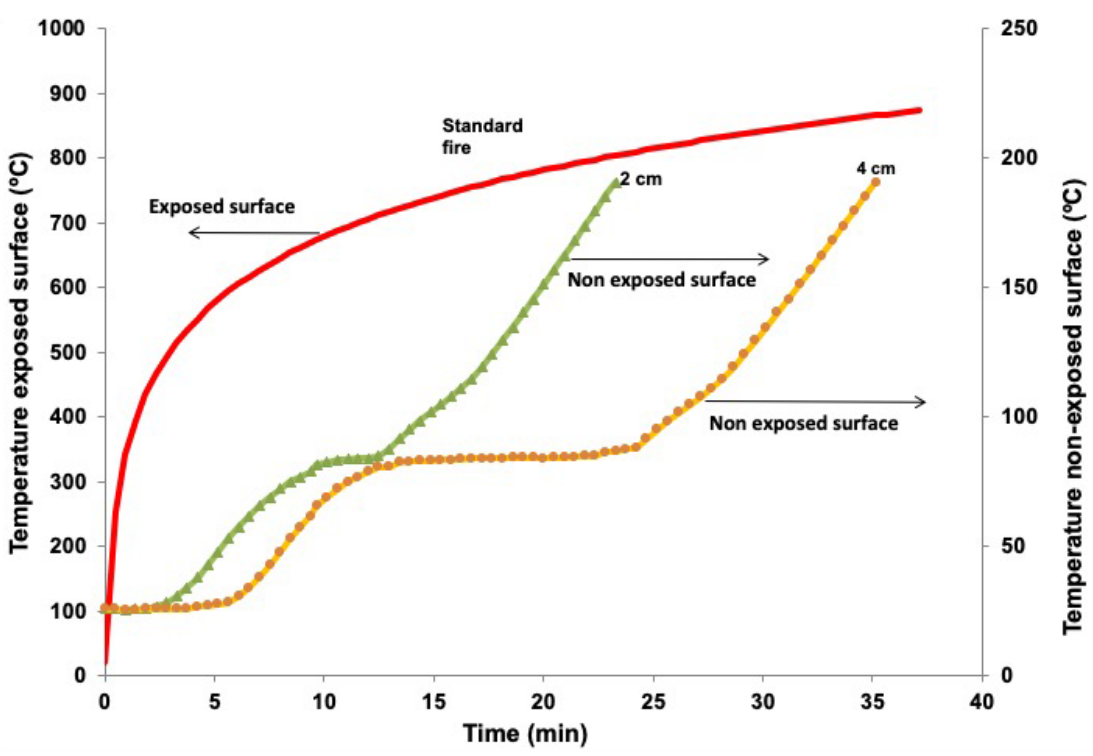

FigURE 4. Fire resistance of the barrier.

\subsection{Leaching properties}

The introduction section of the EN 1794-2 (21) reads as follows: "While performing their primary function, road traffic noise reducing devices should not pose hazards to road users or other people in the vicinity or to the environment at large". It also states: "They (the noise reducing devices) should be made from materials which do not emit noxious fumes or leachates as the result of natural or industrial processes or as the result of fire".

For fly ash, the major environmental concern should be the emission of heavy metals (particularly Mo) through leaching into the groundwater, according to the results presented in Table 1. Despite this, neither leaching tests nor maximum values to limit their use can be found in the specific literature on road traffic noise reducing devices.

The Dutch Decree of Soil Quality (DSQ) (45) is considered the leaching standard reference. The DSQ contains test methods and limits for any waste in any construction material in order to prevent the pollution of the surface water and soil. NEN 7345 is the test established by DSQ for monolithic construction materials that contain wastes. The results of the leaching test of the fly-ash barrier compared to the DSQ limits are shown on Table 6. The use of a product composed essentially of fly ash does not pose any leaching problem according to the DSQ. The Mo concentration was slightly below the DSQ limit due to the stabilization of Mo produced by the cement in the matrix of the barrier.

TABLE 5. Physical and mechanical properties before and after the fire test.

\begin{tabular}{ccccc}
\hline & Density $\left(\mathbf{k g} / \mathbf{m}^{3}\right)$ & \multicolumn{2}{c}{ Superficial hardness (Shore-C) } & Flexural strength (MPa) \\
\hline Before & 886.9 & 42.0 & 1.3 \\
After & 798.2 & Exposed surface & 37.6 & 0.9 \\
& & Non-exposed surface & 32.4 & \\
\hline
\end{tabular}

TABLE 6. NEN 7345 results compared to the DSQ limits.

\begin{tabular}{lccccccccc}
\hline Elements & $\mathbf{H g}$ & $\mathbf{S e}$ & $\mathbf{P b}$ & $\mathbf{S n}$ & $\mathbf{C d}$ & $\mathbf{B a}$ & $\mathbf{C o}$ & $\mathbf{S b}$ & $\mathbf{F}^{-}$ \\
\hline FA Barrier & $<0.2$ & $<0.4$ & $<0.2$ & $<0.3$ & $<0.2$ & 9.7 & $<0.2$ & $<0.4$ & $<32.4$ \\
Limits $\left(\mathbf{m g} / \mathbf{m}^{2}\right)$ & 0.43 & 1.4 & 120 & 26 & 1.1 & 600 & 29 & 3.7 & 1300 \\
\hline Elements & $\mathbf{V}$ & $\mathbf{C r}$ & $\mathbf{M o}$ & $\mathbf{A s}$ & $\mathbf{Z n}$ & $\mathbf{N i}$ & $\mathbf{C u}$ & $\mathbf{C l}$ & $\mathbf{S O}_{4}{ }^{-}$ \\
FA Barrier & 11.2 & 6.8 & 11.5 & $<0.2$ & $<0.2$ & $<0.7$ & $<0.2$ & 663.1 & 1605.6 \\
Limits $\left(\mathbf{m g} / \mathbf{m}^{2}\right)$ & 230 & 140 & 14 & 41 & 200 & 50 & 51 & 18000 & 27000 \\
\hline
\end{tabular}




\section{CONCLUSIONS}

We analyzed a noise reducing barrier composed of $60 \mathrm{wt} . \%$ of fly ash, $25 \mathrm{wt} . \%$ of cement, $14.5 \mathrm{wt} . \%$ of vermiculite and $0.5 \mathrm{wt} . \%$ of fibers from an acoustic, physical, mechanical and environmental perspective, encompassing all the requirements for noise reduction devices according to the European standards.

Regarding its acoustic performance, the barrier was categorized as a typical concrete barrier. $\mathrm{DL}_{\alpha}$ led to its classification as $\mathrm{A} 2$ and $\mathrm{DL}_{\mathrm{R}}$ led to its classification as B3.

Regarding the non-acoustic performance of the barrier, it was classified as having medium density. Compressive strength was lower than that of porous acoustic barriers. The addition of fibers increased its flexural strength above 0.6 MPa. Superficial hardness was lower due to the elastic effect of the vermiculite. The barrier had an adequate impact resistance, only showing small surface layer degradation $(<20 \mathrm{~mm})$. A barrier of $120 \mathrm{~mm}$ thickness had a fire resistance greater than $110 \mathrm{~min}$, and preserved its integrity after the fire test. Despite the high fly ash content, the barrier did not present any environmental and human risks due to the leaching of heavy metals according to the Dutch standard to conduct the monolithic leaching test of construction materials that contain wastes.

\section{ACKNOWLEDGMENTS}

The authors would like to acknowledge the partial financial support provided by the Spanish Ministry of Economy and Competitiveness under project BIA2016-75431-R.

\section{REFERENCES}

1. European Environmental Agency. Noise in Europe (2014). https://www.eea.europa.eu/publications/noise-in-euro pe-2014/file. June 05, 2020.

2. Asdrubali, F.; Schiavoni, S.; Horoshenkov, K.V. (2012) Review of sustainable materials for acoustic applications. Building Acoustics. 19 [4], 283-312. http://doi.org/10.12 60/1351-010X.19.4.283.

3. Spanish Law $22 / 2011$ of 28 July on Waste and Contaminated Soil, Official Spanish Journal, 29 July 2011.

4. Directive 2008/98/EC of the European Parliament and of the Council of 19 November 2008 on waste and repealing certain Directives.

5. Arenas, C.; Vilches, L.F.; Leiva, C.; Alonso-Fariñas, B.; Rodríguez-Galán, M. (2016) Recycling ceramic industry wastes in sound absorbing materials. Mater. Construcc. 66 [324], e106. http://doi.org/10.3989/mc.2016.10615.

6. American Coal Ash Association. Coal ash production and use. (2019). https://www.acaa-usa.org/Portals/9/Files/PDFs/ Coal-Ash-Production-and-Use.pdf.

7. Luna Galiano, Y.; Leiva, C.; Arenas, C.; Arroyo, F.; Vilches, L.; Fernández Pereira, C.; Villegas, R. (2017) Behaviour of fly ash-based geopolymer panels under fire. Waste Biomass Valori. 8 [7], 2485-2494. http://doi.org/ 10.1007/s12649-016-9803-y.

8. Leiva, C.; Vilches, L.F.; Arenas, C.; Delgado, S.; Fernández Pereira. C. (2012) Potential recycling of bottom and fly ashes in acoustic mortars and concretes. ACI Mater. J. 109 [5], 529-535.

9. EN 197-1. Cement. Part 1: Definition, specifications and conformity criteria. European Committee for Standardization. Brussels, Belgium, 2011.

10. Rashad, A.M. (2016) Vermiculite as a construction material - A short guide for Civil Engineer. Constr. Build. Mater. $125,53-62 . \quad$ http://doi.org/10.1016/j.conbuildmat.2016. 08.019 .

11. Leiva, C.; Arenas, C.; Vilches, L.F.; Alonso-Fariñas, B.; Rodriguez-Galán, M. (2015) Development of fly ash boards with thermal, acoustic and fire insulation properties. Waste Manage. 46, 298-303. http://doi.org/10.1016/ j.wasman.2015.08.027.

12. Ríos, J.D.; Cifuentes, H.; Leiva, C.; Ariza, M.P.; Ortiz, M (2020) Effect of polypropylene fibers on the fracture behavior of heated ultra-high performance concrete. Int. J. Fract. 223 [1-2], 173-187. http://doi.org/10.1007/ s10704-019-00407-4.

13. ASTM D3682-13, Standard Test Method for Major and Minor Elements in Combustion Residues from Coal Utilization Processes, ASTM International, West Conshohocken, PA, 2013

14. ASTM C618-17, Standard Specification for Coal Fly Ash and Raw or Calcined Natural Pozzolan for Use in Concrete, ASTM International, West Conshohocken, PA, 2017.

15. EN 1097-7:2009. Test for mechanical and physical properties of aggregates. Part 7: Determination of the particle density of filler. Pyknometer method. European Committee for Standardization. Brussels, Belgium.

16. EN 12457-4:2003. Characterisation of waste: Leaching. Compliance test for leaching of granular waste material and sludges. Part 4: One stage batch test at a liquid to solid ratio of $10 \mathrm{l} / \mathrm{kg}$ for materials with particle size below $10 \mathrm{~mm}$ (without or with size reduction). European Committee for Standardization. Brussels, Belgium.

17. Council Decision 2003/33/EC of 19 December 2002 establishing criteria and procedures for the acceptance of waste at landfills.

18. Ríos, J.D.; Cifuentes, H.; Leiva, C.; Seitl, S. (2019) Analysis of the mechanical and fracture behavior of heated ultra-high-performance fiber-reinforced concrete by X-ray computed tomography. Cem. Concr. Res. 119, 77-88. http:// doi.org/10.1016/j.cemconres.2019.02.015.

19. EN 1793-1:2017 Road traffic noise reducing devices. Test method for determining the acoustic performance. Part 1: Intrinsic characteristics of sound absorption. European Committee for Standardization. Brussels, Belgium.

20. EN 1794-1:2018. Road traffic noise reducing devices Non-acoustic performance - Part 1: Mechanical performance and stability requirements. European Committee for Standardization. Brussels, Belgium.

21. EN 1794-2:2011. Road traffic noise reducing devices Non-acoustic performance - Part 2: General safety and environmental requirements. European Committee for Standardization. Brussels, Belgium.

22. EN 1794-3:2016. Road traffic noise reducing devices Non-acoustic performance - Part 3: Reaction to fire Burning behaviour of noise reducing devices and classification. European Committee for Standardization. Brussels, Belgium.

23. EN 14388:2016. Road traffic noise reducing devicesSpecifications. European Committee for Standardization. Brussels, Belgium.

24. EN ISO 354:2004. Acoustics. Measurement of sound absorption in a reverberation room. European Committee for Standardization. Brussels, Belgium.

25. Del Rey, R.; Alba, J.; Bertó, L.; Gregori, A. (2017) Smallsized reverberation chamber for the measurement of sound absorption. Mater. Construcc. 67 [328], e139. http:// doi.org/10.3989/mc.2017.07316.

26. Díaz, C.; Jiménez, M.; Navacerrada, M.Á.; Pedrero, A. (2012) Acoustic properties of reed panels. Mater. Construcc. 62 [305], 55-66. http://doi.org/10.3989/mc. 2010.60510 . 
27. EN ISO 10140-2:2011. Acoustics - Laboratory measurement of sound insulation of building elements Part 2: Measurement of airborne sound insulation. European Committee for Standardization. Brussels, Belgium.

28. EN 1793-2:2019. Road traffic noise reducing devices - Test method for determining the acoustic performance - Part 2: Intrinsic characteristics of airborne sound insulation under diffuse sound field conditions. European Committee for Standardization. Brussels, Belgium.

29. EN 12390-3:2020. Testing hardened concrete. Part 3: Compressive strength of test specimens. European Committee for Standardization. Brussels, Belgium.

30. EN 12390-5:2020. Testing hardened concrete. Part 5: Flexural strength of test specimens. European Committee for Standardization. Brussels, Belgium.

31. ISO 7892:1988. Vertical building elements -- Impact resistance tests -- Impact bodies and general test procedures. International Organization for Standardization.

32. EN 12859:2012. Gypsum blocks - Definitions, requirements and test methods. European Committee for Standardization. Brussels, Belgium.

33. EN 1936:2007. Natural stone test methods - Determination of real density and apparent density, and of total and open porosity. European Committee for Standardization. Brussels, Belgium

34. EN 1363-1:2015. Fire resistance. Part 1: General requirements. European Committee for Standardization. Brussels, Belgium.

35. NEN 7375:2005. Leaching characteristics of building and solid waste materials. Leaching tests: Determination of the leaching behaviour of inorganic components from shaped building materials, monolithic and stabilized waste materials. Netherlands Standardization Institute (NNI).

36. Arenas, C.; Leiva, C.; Vilches, L.F.; Cifuentes, H.; Rodríguez-Galán, M. (2015) Technical specifications for highway noise barriers made of coal bottom ash-based sound absorbing concrete. Constr. Build. Mater. 95, 585-591. http://doi.org/10.1016/j.conbuildmat.2015.07.107

37. Rios, J.D.; Arenas, C.; Cifuentes, H.; Peceño, B.; Leiva, C (2019) Porous structure by X-ray computed tomography and sound absorption in pervious concretes with air cooled blast furnace slag as coarse aggregate. Acoust. Aust. 47, 271-276. http://doi.org/10.1007/s40857-019-00162-5.

38. Carbajo, J.; Esquerdo-Lloret, T.V.; Ramis, J.; NadalGisbert, A.V.; Denia, F.D. (2015) Acoustic properties of porous concrete made from arlite and vermiculite lightweight aggregates. Mater. Construcc. 65 [320], e072. http://doi.org/10.3989/mc.2015.01115.

39. https://www.panelesach.com/pantallas-barreras-acusticas$\mathrm{ACH}, \mathrm{Feb} 2,2021$.

40. http://www.obralia.com/dir/minisites/catalogos/419295/ catalogo.pdf, May 22, 2020.

41. Sheng Tie, T; Hung Mo, K. Putra, A.; Chuing Loo, S. Johnson Alengaram, U.; Ling, T-C. (2020) Sound absorption performance of modified concrete: A review. $J$. Build. Eng. 30, 101219. http://doi.org/10.1016/ j.jobe.2020.101219.

42. Ríos, J.D.; Arenas, C.; Cifuentes, H.; Vilches, L.F.; Leiva, C. (2020) Development of a paste for passive fire protection mainly composed of granulated blast furnace slag. Environ. Prog. Sustain. Energy. 39 [3], e13382. http:// doi.org/10.1002/ep. 13382 .

43. Leiva, C.; Arenas, C.; Alonso-Fariñas, B.; Vilches, L.F.; Peceño, B.; Luna-Galiano, Y.; Rodriguez-Galán, M. (2018) Fire-resistant panels composed only of combustion byproducts. P. Inst. Civil Eng-Construct. Mater. 171 [1], 36-44. http://doi.org/10.1680/jcoma.16.00018.

44. Deloge Ariyanayagam, A.; Mahendran, M. (2017) Fire tests of non-load bearing light gauge steel frame walls lined with calcium silicate boards and gypsum plasterboards. Thin-Wall. Struct. 115, 86-99. http://doi.org/10.1016/ j.tws.2017.02.005.

45. Decree of Soil Quality (2007). Dutch Ministry of Housing Spatial Planning and the Environment. 